\title{
Factors Affecting Disclosure Levels of Environmental Accounting Information: The Case of Vietnam
}

\author{
La Soa Nguyen ${ }^{1}$, Manh Dung Tran ${ }^{2}$, Thi Xuan Hong Nguyen ${ }^{1} \&$ Quoc Hoi Le ${ }^{2}$ \\ ${ }^{1}$ Hanoi University of Industry, Vietnam \\ ${ }^{2}$ National Economics University, Vietnam \\ Correspondence: Manh Dung Tran, Room No. 202, A14, Living quarter of National Economics University, Hai Ba \\ Trung District, Hanoi, Vietnam.
}

Received: September 5, 2017

Accepted: October 16, $2017 \quad$ Online Published: October 17, 2017

doi:10.5430/afr.v6n4p255

URL: https://doi.org/10.5430/afr.v6n4p255

\begin{abstract}
This research is conducted for assessing factors affecting disclosure levels of environmental accounting information of construction firms in Vietnam. Data were collected from 74 construction firms listed on Vietnam Stock Exchange for the period from 2013 to 2016. Based on quantitative research method, the disclosure levels of accounting information and factors affecting this level were scrutinized. The results indicate that the disclosure levels of environmental accounting information of construction firms tends to increase, especially in 2016. In addition, the results also point out that the level of disclosure is influenced by factors of firm size, profitability, financial leverage, number of years listed and independent audit. Through findings, some recommendations are given for improving the disclosure levels of environmental accounting information to satisfy the demand for information of the stakeholders in the context of integration.
\end{abstract}

Keywords: Environmental accounting information, Information disclosure, Vietnam

\section{Introduction}

Globalization, international economic integration and trade liberalization have been outstanding trends in the modern world economy. The process of deepening, broadening and effective integration of Vietnam into the world economy has brought about great achievements for the country in general as well as firms in particular. Vietnamese firms have more opportunities to enter the global market and integrate deeper into the world financial market for accessing foreign capital. However, many countries in the world have been investing heavily in green growth strategies. They are particularly interested in combating and removing access to markets of imported products that do not comply with the production process and do not meet the requirements of environmental protection. In that context, Vietnamese firms with stable and strong development need to pay attention to environmental and social responsibility apart from getting profits.

Business activities have two sides of positive and negative impacts on the environment, the environment also contributes to the advantages or disadvantages in production and business activities of firms. Therefore, the accounting and information on revenue and environmental costs will help firms understand clearly the relationship between business activities and the environment. Moreover, it will enhance the prestige and image of the business with domestic and foreign partners. This is also the reason for the business community in the countries participating free trade agreements can not ignore the disclosure of information about activities and measures to protect environment.

Vietnam is a member of many free trade agreements including TPP, so the implementation and disclosure of environmental accounting information by Vietnamese firms is considered as a key factor. It is also a necessary condition helping firms improve competitive capacity and develop sustainably in the context of global economic integration. Circular No. 155/2015/TT-BTC issued by Ministry of Finance, effective from January 1, 2016, mandates public firms to publish some environmental information for sustainable development goal. Nowadays, in Vietnam, many firms are aware of the importance of disclosure and transparency of environmental accounting information. However, the level of information disclosure of firms listed on Vietnam Stock Exchange remains relatively different. Therefore, this study is conducted for reviewing and evaluating factors affecting the disclosure levels of environmental accounting information in listed construction firms. Research contributes to proposing direction and 
effective solutions to motivate Vietnamese firms to implement and publish environmental accounting information in the coming time.

\section{Literature Review}

In developed countries, environmental accounting has received the attention of both academics and business executives. Although officially mentioned in the guidelines on environmental accounting by the United Nations Commission on Sustainable Development (UNCSD) in 2001 and The International Federation of Accountants (IFAC) in 2005, environmental accounting in practice has been investigated since 1970s, and implemented in many firms in developed countries since 1990s. In the field of research, scientific papers on environmental accounting appeared very early in the 1970s, but it was not until the 1990s that there were more and more researches conducted, with 40 works and research papers on environmental accounting is published each year on average. In particular, the period from 1997 to now is considered to be a boom period for studies related to environmental accounting. In addition to popular research such as the theoretical studies related to environmental accounting, research on how to apply practical accounting practices to businesses in different fields, studies on factors influencing the application of environmental accounting and factors affecting the disclosure levels of environmental accounting information are also of great concerns (Doan \& Tran, 2017).

Arif \& Tuhin (2013) evaluated the factors affecting the voluntary disclosure related to the environment and society in annual reports of listed banks in Bangladesh. The study employed the disclosure index with 48 voluntary non-financial information disclosures. The sample of 20 banks listed on the Dhaka Stock Exchange was investigated to examine the effect three following characteristics such as the number of years the bank operations, the bank size and the level of annual profitability to the extent of disclosure of information related, to the environment and society of the bank. The results show that the number of years of operation and annual profitability of the bank significantly influenced the disclosure level of non-financial information, while the size of the bank did not.

Wachira (2014) examined environmental accounting practices in 30 firms in different fields in Nairobi, Kenya. Basing on the legislative, institutional and managerial theories, the authors have taken some influential factors into model for verification including firm size, compliance costs, technology, years of operation, environmental strategy and financial activities. Research results indicate that the level of technology is likely to affect, but at a very low level. Compliance costs, environmental strategies and financial performance are key influencing factors. Size and age of firms have no affect the level of environmental accounting management application. Defensive strategy and hierarchical culture are factors that impede the application of environmental management accounting.

Jamil et al. (2015) conducted a survey of the factors and barriers that affect the practice of environmental accounting management in small and medium firms in Malaysia. The results indicate that most firms allocate funds for environmental activities and environmental accounting practices in non-monetary aspects. This study considered coercion as the main factor leading to environmental accounting practices. Financial constraints and guidance shortages are major barriers to the level of management accounting performance in these firms. As a result, the barriers to the development of environmental accounting would be addressed primarily by the Malaysian government and authorities.

Majeed et al. (2015) investigated factors affecting the level of disclosure of information about environmental and social responsibility of listed firms in Pakistan. The study was conducted with a sample of 49 firms with annual reports from 2007 to 2011. The study looked at factors including: board size, the degree of board independence, nationality and gender of the representative on the board, the degree of decentralization, the size and the profit of the business. They found that there is a positive and significant impact of the size of the board. The level of board independence, the degree of decentralization and the size of the business have a noticeable impact on the level of disclosure corporate social and environmental responsibility. The results also show the reverse relationship between the representatives by genders and the disclosure level of environmental information.

The study by Barakat et al. (2015) was carried out for characterizing and evaluating the activities of the extent of disclosure of environmental responsibility of firms in Palestine and Jordan. They detected the disclosure level of environmental accounting information in firms in Jordan is higher than that of Palestinian firms in all aspects. However, compared to the western countries, the level of information disclosure of both countries is low. It means that firms in Jordan are very interested in resources and commitment to the community compared to other firms in Palestine. To explain this difference, the study has demonstrated that the legal system, the characteristics of external auditing firms and the characteristics of corporate governance have a positive relationship with the level of disclosure of information environmental responsibility of the business. 
Hasan \& Hosain (2015) investigated factors that influence the level of mandatory and voluntary disclosure of environmental and social of firms listed on the Dhaka stock exchange. Factors studied include firm size, age of operations, profitability and business lines. The study used multivariate regression analysis and the data was collected from 54 corporate annual reports for the period from 2010 to 2013 of listed firms. Research samples accounted for $21.9 \%$ of the total. The results showed that the firm size significantly and positively affects the level of information voluntary disclosure. Age factor remarkably influences the level of compulsory disclosure. The study also showed that firm size and profit do not affect mandatory disclosure.

Recent studies on environmental accounting in Vietnam are mainly on the application of environmental accounting to various types of enterprises, such as Le and Pham (2016). They investigated the environmental cost management accounting in Vietnam brick production firms. They used quantitative methods to collect and process information on the level of application environmental cost management accounting of the brick production. Research results indicate that the level of application is relatively low and there is a close relationship between the level of performance of environmental cost management accounting and the business performance. Since then, they made some suggestions to promote the implementation of environmental cost management accounting in these firms. However, the study was limited to the results of the assessment of the level of applicability but did not analyze the causal factors.

Nguyen and Thu (2017) evaluate the impact of accounting and disclosure of environmental accounting information on the ability of Vietnamese firms to access foreign finance, based on survey of 104 foreign investors working in Thang Long, Quang Minh and Noi Bai industrial zones. The results show that the disclosure of information on environmental accounting has a strong impact on the decision of foreign investors, thus affecting the ability to access foreign capital of firms. The importance of environmental accounting information in ascending order is (i) timeliness of information, (ii) reliability of information, (iii) completeness of information. They also give some recommendations for improving environmental accounting in Vietnamese firms. However, they focus on assessing the demand for management accounting information of foreign investors without analyzing factors affecting the level of provision of environmental accounting information in general.

Doan and Tran (2017) review and evaluate the level of social responsibility information disclosures in the annual reports of listed firms on the Vietnam Stock Exchange and identify the factors that influence this level. The results show that the level are low. Factors that influence the level of disclosure such as size of business, financial leverage, size of board of directors, independence of executive directors and independent auditors are found in the study. However, the study was conducted jointly for all firms in different business fields without considering the impact of those. Moreover, the study do not mention in details about environmental accounting information to propose future improvements.

Thus, there have been a lot of studies conducted locally and internationally on the factors affecting the ability to provide non-financial, social responsibility information, environment and factors influencing the ability to apply environmental accounting to different types of firms. However, because the construction firms in Vietnam have their own characteristics of management organization, production and business system, the level of environmental impact in the process of business operations and production. Therefore, in the dimension of this research, wee look into factors influencing disclosure levels of environmental accounting information with the case of listed construction firms in Vietnamese context.

\section{Theoretical Background and Research Hypotheses}

\subsection{Theoretical Background}

Research views on environmental accounting argue that environmental accounting is judged in two aspects, accounting and environmental management. In addition to supporting internal decision making in the business operations of the business with the view to improving financial and environmental performance, environmental accounting also provides information outside the business to stakeholders such as banks, financial institutions, environmental management agencies, communities, etc. Thereby it helps businesses to (i) enhance competitive advantage due to green consumption of clean products, (ii) change and increase the level of awareness and action of organizations and stakeholders on environmental issues in each firm and the economy as a whole. Thus, the sufficient, timely and accurate information environmental accounting disclosure of construction firms listed on the stock market in Vietnam plays an important role not only for businesses, investors but also for state management agencies. To explain the disclosure of environmental accounting information of enterprises, we use the following theories as 
Theory of Legitimacy and Responsibility for Publicizing Environmental Accounting Information: Legitimacy Theory is defined by Dowling and Pfeffer (1975) as follows: "An entity can exist when its value system is consistent with the value system of the larger social system in which it is located" Inheriting and developing the theory of legalization, Guthrie and Parker (1989) argue that the theory of legalization is related to the power of society. They found that business enterprises in society must sign a social contract that managers agree to implement. The terms of this contract may be specified in terms of legal provisions or unspecified depending on the expectations of the social community. Legal theory explains the responsibility for implementing environmental accounting of enterprises as the necessity to implement environmental accounting derives from society, government's dissatisfaction and the pressure from demand of workers, consumers and stakeholders (Toukabri et al., 2014). Environmental disclosure is a motivation for businesses to legitimize their activities, thereby promote their image that benefits them (Lindlom, 1994). Thus, disclosing public environmental information in annual reports is a strategic representation of the business. This strategy implies that the business is operating legally and has social responsibility.

Relevant stakeholder theory and the responsibility to disclose environmental accounting information: The Stakeholder Theory is derived from the perspective of economic interests in all actions by the economist Freeman (1984). According to Freeman (1984), all stakeholders are affected by all business behaviors, including shareholders, suppliers, customers, employees, competitors, social workers, lawmakers, academics, indigenous peoples, labor organizations, local administration and the government. Based on stakeholder theory, Ullmann (1985) explained that if a stakeholder controls an important source of business, the business will find a way to satisfy their needs. Environmental information disclosure is considered an effective governance strategy that addresses relationships and satisfies needs of stakeholders. On the other hand, the study by Roberts (1992), Chiu and Wang (2014) showed that return on equity ROE is positive and debt to equity ratio is reverse to the disclosure of information about the environment.

Relationship Between Cost \& Benefit And Levels Of Environmental Accounting Information Disclosure Theory: The Cost Benefit Theory shows that the benefits of disclosure of environmental accounting information should be considered in relation to the cost of creating and providing that information. Thus, the level of disclosure of environmental accounting information should be taken into consideration between the added benefits and the increased costs when performing this task.

\subsection{Research Hypothesis}

Based on literature review on factors affecting the level of disclosure of environmental accounting information and theories concerning the disclosure level of environmental accounting information, we synthesize the factors affecting the disclosure quality of environmental accounting information of construction firms listed on Vietnam's Stock Exchange as follows:

Business Size (SIZE): Previous empirical studies showed that the firm size affects the level of disclosure of its environmental accounting information. The larger the size of the business, the more likely publish environmental accounting information. Large firms are always confident of their prospects, so they are often willing to spend expense to publicize more voluntary information in order to make a difference to rival businesses and increase its value (Hasan and Hosain, 2015). In addition, the larger the firm is, the more it wants to maintain and enhance its image, belief and prestige in the eyes of investors and government agencies, so more money is spent for disclosing information to meet the requirement of stakeholders (Wachira, 2014). Moreover, for large firms, the accounting system is relatively effective, the accounting information system satisfies the demand for information in terms of quality and quantity, so the disclosure of more environmental accounting information will be less costly than that of small firms. Therefore, the first hypothesis about factors affecting the disclosure level of environmental accounting information of listed construction firms is:

H1: The larger construction firms listed on the stock market of Vietnam are, the higher the disclosure level of environmental accounting information is

Profitability (PRO): According to stakeholder theory, the more profitable firms are, the more ambitious they are to meet and satisfy the information needs of the stakeholders, especially the stakeholders are in control of the important resources of the firm. It is an opportunity for firms to increase the value of their stock in the market. The greater the financial performance is, the more they are willing to devote their financial resources to the development of a sustainable environment in which they operate. Therefore, the second hypothesis about factors affecting the disclosure level of environmental accounting information of listed construction firms is: 
H2: The higher profitability construction firms listed on Vietnam's stock market have, the higher the disclosure level of environmental accounting information is

Leverage (LEV): According to stakeholder theory, the higher the financial leverage is, the higher the debt to equity ratio is, the greater the conflict of interest between the parties involved is, such as debtors, shareholders and managers. The requirements for providing information to satisfy the stakeholders is also higher. However, firms with higher debt ratios often face financial difficulties and solvency, so according to cost and benefit theory, it is very difficult for them to decide on expense on environmental and social issues. Empirical study by Chiu and Wang (2014) also showed that the debt-to-equity ratio is reverse to the level of disclosure. Therefore, the third hypothesis about factors affecting the disclosure level of environmental accounting information of the listed construction firms is:

H3: The higher the financial leverage of construction firms listed on the stock market in Vietnam is, the lower the disclosure level of environmental accounting information is

The age of being listed on the stock market (AGE): Wachira (2014) study has shown that the firm's age does not affect the level of disclosure of environmental accounting information. In contrast, the study by Hasan \& Hosain (2015) showed that business's age has a significant effect on the level of mandatory information disclosure. However, according to the theory of legalization, the longer the firms is listed on the stock market, the easier they will be to comply with the disclosure requirements. In terms of additional disclosure, the extra cost they have to spend is not much higher than that of young firms. So in cost and benefits theory, these firms will tend to spend cost for the disclosure of environmental accounting information. Therefore, the fourth hypothesis about factors affecting the level of disclosure of environmental accounting information of the listed construction firms is:

H4: The longer the period of being listed on the stock market is, the higher the disclosure level of environmental accounting information is

Independent Audit (AUD): In order to maintain their reputation and prestige, the more reputable independent auditing firms are, the more likely they are to require higher level of disclosure as well as want their customers to follow the complex accounting standards. Therefore, the fact is that firms actively choose reputable independent auditing firms to audit their own businesses is considered as a good signal in ensuring the information transparency and disclosure of enterprises. Therefore, the fifth hypothesis about factors affecting the level of disclosure of environmental accounting information of listed construction firms is:

H5: The more reputable the audit firm used, the higher the disclosure levels of environmental accounting information is

Table 1. Research Hypotheses

\begin{tabular}{lll}
\hline Hypothesis & Description & $\begin{array}{l}\text { Sign } \\
\text { Expectation }\end{array}$ \\
\hline $\mathrm{H}_{1}$ & $\begin{array}{l}\text { The relationship between size and the level of disclosure of environmental } \\
\text { accounting information. }\end{array}$ \\
& $\begin{array}{l}\text { The relationship between profitability and the level of disclosure of } \\
\text { environmental accounting information. }\end{array}$ \\
$\mathrm{H}_{2}$ & $\begin{array}{l}\text { The relationship between financial leverage and the level of disclosure of } \\
\text { environmental accounting information. } \\
\mathrm{H}_{3}\end{array}$ \\
& $\begin{array}{l}\text { The relationship between listing time and level of disclosure of } \\
\text { environmental accounting information. } \\
\mathrm{H}_{4}\end{array}$ & $\begin{array}{l}\text { The relationship between independent auditors and the level of disclosure } \\
\text { of environmental accounting information. }\end{array}$ \\
$\mathrm{H}_{5}$ &
\end{tabular}

\section{Research Methodology}

\subsection{Data Collection}

The sample includes 74 large listed construction firms on Vietnam Stock Exchange, and its market capitalization occupies $83.8 \%$ total market capitalization of all construction firms as of 31 December 2016. Data are collected from 2013 to 2016. Financial information of listed firms is obtained from the website of finance.vietstock.vn. Environmental accounting information is disclosed from annual reports in which financial statements have been audited, sustainable reports and business administration reports published on the websites of 74 firms in the sample. 
The data used for the analysis includes 296 observation variables of 74 firms in four consecutive years from 2013 to 2016.

\subsection{Variable Measurements}

\section{Dependent variable measurement (ENVI) - Disclosure level of environmental accounting information}

According to the Global Reporting Initiative's (2013) Sustainable Development Report Guidelines, the total number of items for disclosure of mandatory environmental accounting information is 34 items in the 12 relevant fields as Table 2:

Table 2. Items for Mandatory Environmental Information Disclosures

\begin{tabular}{|c|c|c|c|c|c|}
\hline No. & Sectors & $\begin{array}{l}\text { No. of items } \\
\text { have to be } \\
\text { disclosed }\end{array}$ & No. & Sectors & $\begin{array}{l}\text { No. of items } \\
\text { have to be } \\
\text { disclosed }\end{array}$ \\
\hline 1 & Material & 2 & 7 & $\begin{array}{l}\text { Information on label of products and } \\
\text { services }\end{array}$ & 2 \\
\hline 2 & Energy & 5 & 8 & Compliance & 11 \\
\hline 3 & Water & 3 & 9 & Transportation & 1 \\
\hline 4 & Biodiversity & 4 & 10 & Overall & 1 \\
\hline 5 & Emissions & 7 & 11 & Supplier's Review of the Environment & 2 \\
\hline 6 & $\begin{array}{l}\text { Wastewater and } \\
\text { Waste }\end{array}$ & 5 & 12 & Environmental complaints mechanism & 1 \\
\hline
\end{tabular}

To assess the extent of disclosure of environmental accounting information, information regarding the criteria is scored in Table 3.

Table 3. Method for Assessing Disclosure Levels of Environmental Information

\begin{tabular}{ll}
\hline Level of Information Disclosure & Score \\
\hline Publication information is both quantitative and qualitative form & 4 \\
Only qualitative, non quantitative disclosure & 3 \\
Quantitative information both in object and value, no qualitative information & 2 \\
Quantitative information on the value, no object and no qualitative information & 1 \\
No information disclosure & 1
\end{tabular}

The disclosure index is calculated according to the weighted approach, depending on the quality of the information provided to assess the score for each item, then averaged for each field and calculated environmental açcounting information disclosure index. The formula is as follows: The level of information disclosure of firms $\mathrm{X}=\frac{\sum_{i=1}^{3+} Y i}{34}$ (Yi is the score of information item i published by firm X). Similarly, research has calculated the level of information disclosure by field.

\section{Measurement of independent variables}

Independent variables are measured and presented in Table 4, below:

Table 4. Measurement of Independent Variables

\begin{tabular}{lll}
\hline Code & Independent Variable & Measurement \\
\hline SIZE & Business Size & Log (Total Assets) \\
PRO & Profitability & Profit after tax divided by equity \\
LEV & Financial Leverage & Total long-term debt divided by total assets \\
& & Number of years from the beginning of listing to the end of \\
AGE & Listing period & 2016 \\
AUD & Independent Auditor & $=1$, independent auditor of Big $4 ;=0$, the rest \\
\hline
\end{tabular}


In order to achieve the objective of investigating the factors affecting the disclosure level of environmental accounting information, the study conducted the test of hypotheses from $\mathrm{H} 1$ to $\mathrm{H} 5$ with the support of data analysis software of Stata. Multivariate linear regression was applied to the model as follows:

$$
\text { ENVI }=\beta 0+\beta 1 \text { SIZE }+\beta 2 \text { PRO }+\beta 3 \text { LEV }+\beta 4 \text { AGE }+\beta 5 \text { AUD }+e
$$

\section{Results and Discussion}

\subsection{Evaluations of Disclosure Levels of Environmental Accounting Information}

Table 5 describes the environmental accounting information disclosures index of firms in the sample.

Table 5. Assessment Results of the Disclosure Levels of Environmental Accounting Information

\begin{tabular}{llllll}
\hline No & Information disclosure field & $\mathbf{2 0 1 3}$ & $\mathbf{2 0 1 4}$ & $\mathbf{2 0 1 5}$ & $\mathbf{2 0 1 6}$ \\
\hline 1 & Materials & 1.613 & 1.795 & 1.813 & 1.995 \\
2 & Energy & 1.543 & 1.695 & 1.745 & 1.865 \\
3 & Water & 1.364 & 1.746 & 1.960 & 2.357 \\
4 & Biodiversity & 1.492 & 1.696 & 1.893 & 2.369 \\
5 & Emissions & 1.556 & 1.654 & 1.754 & 1.867 \\
6 & Wastewater and waste & 1.814 & 1.941 & 1.975 & 2.184 \\
7 & Information on label of products and services & 1.945 & 2.087 & 2.067 & 2.947 \\
8 & Compliance & 1.656 & 1.706 & 1.857 & 2.487 \\
9 & Transportation & 1.679 & 1.815 & 1.861 & 2.094 \\
10 & Overall & 1,856 & 2.087 & 2.209 & 2.812 \\
11 & Supplier's Review of the Environment & 1.386 & 1.498 & 1.287 & 2.910 \\
12 & Environmental complaints mechanism & 1.612 & 2.143 & 2.574 & 2.943 \\
\hline
\end{tabular}

As can be seen from Table 5, mean values of the environmental accounting disclosure indicators have been gradually increasing during 2013 and 2016. This shows a good signal that construction firms in Vietnam are paying attention to the release of information on environmental indicators, especially after the detailed guidance of Circular No. 155/2015/TT-BTC dated $6^{\text {th }}$ October 2015 issued by Ministry of Finance. This is shown by the mean value of the environmental accounting disclosure indicators in 2016 compared to the previous years. However, with the highest score calculated for each item of 4, the average value of this indicator in each field ranged from 1.364 to the highest point of 2.947. It points out that the attention to disclosure of environmental accounting information in the past was not in correspondence with its importance. The two groups of information elements that mostly disclosed by listed firms are information on the environmental complaint mechanism (2.943 in 2016), i.e. the number of complaints about environmental impacts filed, processed and resolved through formal complaint mechanisms, and information on label of products and services (2.947 by 2016). However, some important fields receiving special concerns from stakeholders have lower score, for example energy only scores 1.865 , emissions scores 1.867 , wastewater and waste scores 2.184 in 2016.

\subsection{Evaluation of Correlation between Variables}

Table 6 presents basic statistical describing parameters of independent variables and dependent variables. According to Tauchen (1986), condition for estimation of reliability for performing regression analysis is $n>200$. According to Hair et al. (2006), there should be 15-20 observations for a variable to be estimated. Combined with these principles, the sample size chosen by the author with 296 observations of 74 firms is reasonable. The results in Table 6 show that the level of environmental accounting information disclosure is 1.866 and range from 0.276 to 3.235. The size of the business ranges from 5.096 to 15.875 , indicating that the size of the firms in the sample differs widely. The period of listing on the stock market is 10.374 years on average and fluctuates from 8.456 to 16.048 , which proves that the listed firms in the sample are not too young. 
Table 6. Statistical Analysis

\begin{tabular}{lllllll}
\hline & ENVI & SIZE & PRO & LEV & AGE & AUD \\
\hline Number of Observations & 296 & 296 & 296 & 296 & 296 & 296 \\
Mean value & 1.866 & 10.87 & 0.165 & 0.456 & 10.374 & 0.376 \\
Standard Deviation & 2.579 & 4.328 & 0.075 & 0.215 & 3.217 & 0.423 \\
Minimum value & 0.276 & 8.096 & 0.097 & 0.325 & 8.456 & 0.000 \\
Maximum value & 3.235 & 15.875 & 0.216 & 0.776 & 16.048 & 1.000 \\
\hline
\end{tabular}

Table 7 presents the results of the correlation coefficient test between the variables and the results of the multi-collinearity test. The results show that there is a variation between the independent and dependent variables of the model. The level of disclosure of environmental accounting information has positive relationship with the variables of business size, profitability, listing time, and independent auditing, and negative relationship with financial leverage. At the same time, correlated pairs are less than 0.8 and the VIF of independent variables is less than 5 , which proves that there is not multi-collinearity.

Table 7. Correlation and Multi-collinearity Test

\begin{tabular}{llllllll}
\hline & ENVI & SIZE & PRO & LEV & AGE & AUD & VIF \\
\hline ENVI & 1.000 & & & & & & - \\
SIZE & 0.464 & 1.000 & & & & & 2.134 \\
PRO & 0.367 & 0.261 & 1.000 & & & & 2.451 \\
LEV & -0.342 & 0.148 & 0.261 & 1.000 & & & 1.652 \\
AGE & 0.652 & 0.231 & 0.187 & 0.265 & 1.000 & & 2.012 \\
AUD & 0.231 & 0.261 & 0.123 & 0.157 & 0.427 & 1.000 & 1.023 \\
\hline
\end{tabular}

\subsection{Discussions}

Table 8 presents the results of regression using the least squares (OLS), fixed effects model (FEM) and random effects model (REM). The results show that there are differences between the three methods. Therefore, to conclude what results should be used, we conduct two following tests: Step 1: Use Hausman test to decide to use whether FEM or REM method. The p value of Hausman test is 0.000 , therefore the FEM model is more appropriate. Step 2: Use the F_test test to select the result between the FEM or OLS method. The $\mathrm{p}$ value of $\mathrm{F}$ - test is 0.000 , so the FEM model is more appropriate. Thus, the conclusion is that in this case using regression results of the FEM method is best suitable. As a result of this model, H1 to H5 hypotheses are acceptable, business size, profitability, listing time, and independent auditors affect the level of disclosure of construction firms listed on the stock market in Vietnam. The fluctuation of these variables explains 53,625\% of the variation of the dependent variable (the level of disclosure of environmental accounting information). The regression equation is rewritten as:

$$
\text { ENVI }=0.437+0.456 \times \text { SIZE + 0.543 } \times \text { PRO + 0.578 } \times \text { LEV + 0.454 } \times \text { AGE + 0.309 } \times \text { AUD + e }
$$

Table 8. Regression Results

\begin{tabular}{llllllll}
\hline & Constant & SIZE & PRO & LEV & AGE & AUD & $\begin{array}{l}\text { R } \\
\text { Squared }\end{array}$ \\
\hline \multirow{2}{*}{ OLS } & \multirow{2}{*}{0.254} & 0.324 & 0.453 & 0.634 & 0.345 & 0.235 & 0.51224 \\
& & $(.0024)$ & $(.0025)$ & $(.0052)$ & $(.0042)$ & $(.0053)$ & \\
\multirow{2}{*}{ FEM } & \multirow{2}{*}{0.437} & 0.456 & 0.543 & 0.578 & 0.454 & 0.309 & 0.53625 \\
& & $(.0025)$ & $(.000)$ & $(.000)$ & $(.0025)$ & $(.0034)$ & \\
\multirow{2}{*}{ REM } & \multirow{2}{*}{0.328} & 0.432 & .0564 & 0.584 & 0.427 & 0.338 & \multirow{2}{*}{5.09626} \\
& & $(.0072)$ & $(.0040)$ & $(.0034)$ & $(.0028)$ & $(.0025)$ & \\
\hline
\end{tabular}

Where: The values in the first row in each cell are taken from the Coefficient column

The values in brackets are taken from the p_value column of the variable 


\section{Conclusion and Recommendations}

The research results indicate the importance of environmental accounting information disclosure of listed firms in the long-term business strategy. Highly effective firms are often among the top firms in the industry that are well-regarded for their environmental responsibility, as demonstrated by adequate and detailed disclosure of information related to the environment. The disclosure of environmental accounting information is a way for firms to enhance their images and reputations with stakeholders, especially in the integration trend when developed countries are very interested in green growth and sustainable development. However, the situation shows that the accounting work and information disclosure related to the environment have not been properly paid attention by listed construction firms in Vietnam. Therefore, in the coming time, construction firms need to strengthen solutions for improving environmental accounting to support the disclosure of information related. From the research results, we give some recommendations as follows:

First, the firm size and time of listing on the stock market affect positively to the disclosure level of environmental accounting information. In other words, the larger the firm size and the longer listing time is, the higher the disclosure level of environmental accounting information is. In consequence, state agencies and stakeholders should have policies to support and promote small and medium firms, new firms listed on the stock market for implementing and disclosing environmental accounting information.

Second, profitability has the positive impact on the disclosure quality of environmental accounting information. In contrast, financial leverage has a reverse impact. This suggests that one of the measures to promote the disclosure of environmental accounting information is to improve profitability and reduce financial leverage. Therefore, depending on the business strategy of each period, listed firms should have reasonable level of financial leverage adjustment, ensure high profitability and pay attention to the allocation of resources for implementation and disclosure of environmental accounting information.

Third, listed construction firms audited by big 4 auditors usually have the higher level of disclosure of environmental accounting information than that of non big 4 auditors. Therefore, the selection of independent auditors is an important element that the board of directors and executives need to take into consideration. It is also an element of enhancing corporate image and prestige with stakeholders. This is also viewed as a measure to contribute to the completion of environmental accounting in the enterprise.

Basing on the quantitative and qualitative research method, we have assessed the factors influencing the disclosure level of environmental accounting information. The results show that the level of disclosure tends to increase over time and is influenced by factors such as firm size, financial leverage, time of listing and independent audit, from which we propose some recommendations to promote the disclosure level of environmental accounting information in the listed construction firms in the future.

\section{Acknowledgement}

This research is funded by Vietnam National Foundation for Science and Technology Development (NAFOSTED) under grant number 502.01-2015.19

\section{References}

Arif, H.M. \& Tuhin, M.H. (2013). Disclosure of Non-Financial Information Voluntarily in the annual report of Financial institutions: A study on listed banks of Bangladesh. European Journal of Business and Economics, 8(2), 37 - 42. https://doi.org/10.12955/ejbe.v8i2.397

Barakat, F.S.Q., Pepez, M.V.L. \& Ariza. L.R. (2015). Corporate Social Responsibility Disclosure (CSRD) Determinants of listed firms in Palestine (PXE) and Jordan (ASE). Review of Managerial Science, 9, 681-702. https://doi.org/10.1007/s11846-014-0133-9

Chiu, T.K. \& Wang, Y.H. (2014). Determinants of Social Disclosure Quality in Taiwan: An Application of Stakeholder Theory. Journal of Business Ethics, 129(2), 379-398. https://doi.org/10.1007/s10551-014-2160-5

Doan, N.P.A. \& Tran. T.T.B. (2017). Reality and Factors Affecting the Levels of Disclosure of Social Responsibility Information of Listed Enterprises in Vietnam's Stock Market. Proceedings: Research and Training Accounting and Auditing of Vietnamese Universities according to international standards, National Economics University, Vietnam.

Dowling, J. \& Pfeffer, J. (1975). Organizational legitimacy: social values and organization behavior. Pacific Sociological Review, 18(1), 122-136. https://doi.org/10.2307/1388226 
Freeman, R. E. (1984). Strategic Management: A Stakeholder Approach. Boston Pitman.

Global Reporting Initiative. (2013). Guidelines for Sustainable Development Report. The manual of Vietnamese version.

Guthrie, J. \& Parker, L.D. (1989). Corporate social reporting: A rebuttal of legitimacy theory. Accounting and Business Research, 19(76), 343-352. https://doi.org/10.1080/00014788.1989.9728863

Hair, J.F., Black, W.C., Babin, B.J., Anderson, R.E., \& Tatham, R.L. (2006). Multivariate data analysis. Pearson Prentice Hall Upper Saddle River, NJ.

Hasan, M. T., \& Hosain, M. Z. (2015). Corporate Mandate and Voluntary Disclosure Practices in Bangledesh: Evidence from listed companies of the Dhaka Stock Exchange. Research Journal of Finance and Accounting, 6(12), 14-32.

Jamil, C.Z., Mohamed, R. \& Muhammad, F. (2015). Environmental management accounting practices in small and medium manufacturing firms. Procedia - Social and Behavioral Sciences, 172, 619 - 626. https://doi.org/10.1016/j.sbspro.2015.01.411

Le, T. T. \& Pham, T. B. C. (2016). Environmental Cost Management Accounting in Vietnamese Brick Manufacturing Enterprises. Proceedings of International Workshop: Vietnam's Economy in the Integration Era: Opportunities and Challenges, University of Commerce, Vietnam.

Lindblom, C.K. (1994). The Implications of Organizational Legitimacy for Corporate Social Performance and Disclosure. paper presented to the Critical Perspectives on Accounting Conference, New York.

Majeed, S., Aziz, T., \& Sale. S. (2015). The Effect of Corporate Governance Elements on Corporate Social Responsibility (CSR) Disclosure: An Empirical Evidence from Listed Companies at KSE Pakistan. International Journal of Financial Studies, 3(4), 530-556. https://doi.org/10.3390/ijfs3040530

Ministry of Finance. (2015). Circular No.155/2015/TT-BTC dated 6 October 2015 on Guiding the information disclosure on the stock market.

Nguyen, L. S. \& Thu, T. T. M. (2017). Increasing the ability of accessing foreign finance of Vietnamese enterprises looking at the environmental accounting implementation. Proceedings of International Workshop: Promoting access to finance in Vietnam, Banking Academy, Vietnam.

Roberts, R. W. (1992). Determinants of Corporate Social Responsibility Disclosure: An Application of Stakeholder Theory. Accounting, Organizations and Society, 17(6), 595-612. https://doi.org/10.1016/0361-3682(92)90015-K

Tauchen, G. (1986). Finite state markov - chain aporoximations to univariate and vector autoregressions. Economics Letters, 20(2), 177-181. https://doi.org/10.1016/0165-1765(86)90168-0

Toukabri, M., Olfa, B. J. \& Faouzi, J. (2014). Corporate Social Disclosure: The Explanatory Theories and Conceptual Framework. International Journal of Academic Research in Management (IJARM), 3(2), $208-225$.

Ullmann, A. (1985). Data in Search of a Theory: A Critical Examination of the Relationship among Social Performance, Social Disclosure and Economic Performance. Academy of Management Review, 10(3), $540-577$.

Wachira, M. M. (2014). Factor influencing the adoption of environmental management accounting practices among firms in Nairobi, Kenya. Master Thesis, University of Nairobi, Kenya. 